\title{
Publikowane listy czytelników miesięcznika „Szkoła i Dom" jako źródło do badania współdziałania szkoły z rodziną. Zarys problematyki
}

\section{List jako forma wypowiedzi osobistej}

Wśród różnych kategorii materiałów źródłowych, mało dotąd wykorzystywanym źródłem narracyjnym ${ }^{1}$ do dziejów historii edukacji jest korespondencja. Do korespondencji zaliczamy zarówno listy prywatne, jak i listy „kierowane do osób, instytucji czy urzędów reprezentujących w oczach nadawcy władzę lub uznawanych za zdolne do podjęcia interwencji w jakiejś konkretnej sprawie"2. List to pisemna wypowiedź skierowana do osób lub instytucji, natomiast korespondencja to zbiór informacji (listów) jednego autora o cechach bardziej szczegółowych i złożonych ${ }^{3}$. List i korespondencja mieszczą się w szerokim pojęciu dialogu społecznego, „ujawniają i kształtują więź społeczną"4. Jako twory językowe obsłu-

* Dr, Katedra Dydaktyki i Historii Wychowania, Wydział Nauk Społecznych, Uniwersytet Warmińsko-Mazurski, 10-725 Olsztyn, ul. Prawocheńskiego 13.

1 Podział źródeł narracyjnych (opisowych, opowiadających) przyjmuję za Jerzym Serczykiem, który wśród nich wyróżnia: dzieła historiograficzne, biografię, hagiografię, pamiętniki, wspomnienia, relacje, twórczość publicystyczną (czasopisma, gazety, dzienniki, ulotki, materiały propagandowe itp.) oraz korespondencję prywatną i półprywatną; M. P a w l a k, J. S e r c z y k, Podstawy badań historycznych, Bydgoszcz 1991, s. 21, 25.

2 T. S z a r o t a, Baza źródłowa, wiedza pozaźródłowa i literatura przedmiotu w warsztacie historyka współczesności, „Polska 1944/45-1989. Studia i materiały” 2004, nr 6, s. 14.

3 J. Trzy na d l o w s ki, List i pamiętnik - dwie formy wypowiedzi osobistej, „Pamiętnikarstwo Polskie" 1975, nr 1-4, s. 81.

4 S. S k w a r c z y ń s k a, Wokół teorii listu. Paradoksy, „Pamiętnikarstwo Polskie” 1972, nr 4, s. 37. 
gują potrzeby życia codziennego, świetnie odzwierciedlając „stan świadomości społecznej, nastroje chwili, bogaty wachlarz ludzkich postaw i opinii”. Stąd też należy je zaliczyć do dziedziny kontaktów międzyludzkich. Ze względu na usługowy charakter codzienności bazą języka pisanego listu jest język potoczny. List jako utwór użytkowy charakteryzuje się licznymi strukturalnymi odmianami. Ze względu na adresata listu wyróżnia się m.in. list prywatny, list literacki, list apostolski, list rodzinny, list otwarty. Biorąc pod uwagę stosunek wiążący piszącego $\mathrm{z}$ adresatem wymienia się takie odmiany listu jak: list do członka rodziny $\mathrm{np}$. żony, list przyjacielski czy list miłosny ${ }^{6}$.

Zarówno list, jak i korespondencja pełnią rolę informacyjną i dokumentacyjną.

Chociaż listy zawierają interesujące informacje o wydarzeniach ${ }^{7}$, to jednak ich wartość jest różna i zależna od wielu czynników. Podczas krytyki źródła należy zwrócić uwagę m.in. na to, czy listy wysłane i otrzymane zostały zachowane w całości, jaki był wzajemny stosunek osób korespondujących ${ }^{8}$. Strukturę listu wyznacza też jego cel, sytuacyjne okoliczności tworzenia listu, osoba epistolografa i konwencje epistolograficzne ${ }^{9}$. $Z$ tych też powodów analiza materiałów korespondencyjnych jest pracochłonna i przez to dość rzadko sięga się do tego rodzaju przekazu źródłowego ${ }^{10}$.

Analizie zostaną poddane listy od osób prywatnych, które zostały opublikowane na łamach miesięcznika "Szkoła i Dom”. Będą to zarówno „wycinki” listów czytelników do redakcji, jak i ich zbiór. Korespondencja czytelników z redakcją czasopisma „Szkoła i Dom” posłuży do przedstawienia problematyki współdziałania szkoły $z$ rodziną ${ }^{11}$.

\section{Powstanie i rozwój czasopisma „Szkoła i Dom”}

Wraz z przejęciem władzy w państwie przez Polską Zjednoczoną Partię Robotniczą zaczął się kształtować nowy system prasowy. Prasa przyjęła na siebie rolę aktywnego kreowania rzeczywistości, pełniąc przy tym dwie podstawowe

5 T. S za ro ta, Dokumenty autobiograficzne w badaniach dziejów najnowszych, „Pamiętnikarstwo Polskie" 1972, nr 4, s. 80.

${ }^{6}$ S. Skwarczyńs ka, Wokół teorii..., s. 43.

7 D. Jarosz, Listy do centralnych instytucji państwa stalinowskiego jako źródło do badania życia codziennego w Polsce, „Kwartalnik Historii Kultury Materialnej” 1996, nr 3, s. 297-302.

${ }^{8}$ M. Pawlak, J. Serczyk, Podstawy badań..., s. 25.

${ }^{9}$ S. Skwarczyńs ka, Wokół teorii..., s. 43.

10 T. S z a r o ta, Baza źródłowa..., s. 15.

11 Analizą czasopisma „Szkoła i Dom” zajmowali się m.in.: K. Jakubiak, Problematyka wychowania rodzinnego $i$ relacji rodziny $i$ szkoły $w$ polskim piśmiennictwie pedagogicznym $w$ latach 1945-1956, [w:] Oświata, wychowanie i kultura fizyczna w rzeczywistości społeczno-politycznej Polski Ludowej (1945-1989), red. R. Grzybowski, Toruń 2004, s. 211-219; A. O s s o w s k a - Z wi i r z c h o w s k a, Wizerunek rodziców i dzieci w czasopiśmie dla "nowych komitetów rodzicielskich” (,Szkoła i Dom” 1949-1958), „Acta Universitatis Nicolai Copernici” 2010, Pedagogika XXVI, z. 394. 
funkcje - opiniotwórczą i propagandową. Z jednej strony przekazywała treści (zazwyczaj propagandowe) zgodnie z życzeniami dysponenta politycznego ${ }^{12}$, z drugiej zaś stosowała różne sposoby perswazji w celu manipulowania odbiorcą ${ }^{13}$. Niezależnie od środków i intensywności propagowania treści propagandowych, prasa była narzędziem służącym do przebudowy świadomości społeczeństwa.

Za prasę nowego typu, czyli „łącznik między partią a społeczeństwem”14 należy uznać miesięcznik „Szkoła i Dom”"15. Czasopismo to powstało w 1949 r. Pierwszy numer ukazał się we wrześniu pod patronatem Ministerstwa Oświaty i Związku Nauczycielstwa Polskiego (fot. 1). Był to miesięcznik adresowany do rodziców i komitetów rodzicielskich. Oficjalnie informacja ta, jako podtytuł, pojawiła się na stronie tytułowej w pierwszym numerze z 1954 r. (fot. 2). Dwa lata później w jednym z numerów zakomunikowano, że „pismo jest w zasadzie przeznaczone dla aktywi-

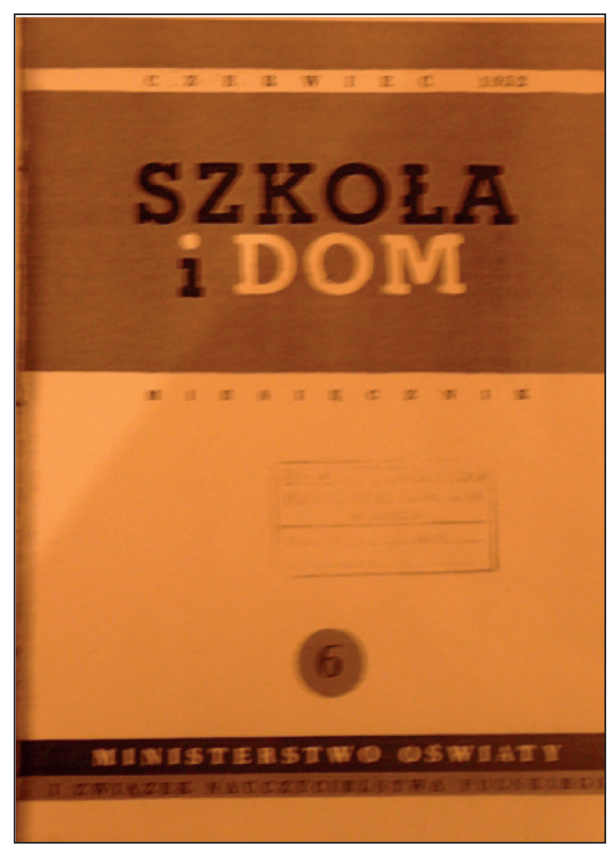

Fot. 1. Strona tytułowa miesięcznika „Szkoła i Dom” 1952, nr 6

Źródło: Warmińsko-Mazurska Biblioteka Pedagogiczna im. prof. T. Kotarbińskiego w Olsztynie stów komitetów rodzicielskich pracujących w szkołach podstawowych"16.

Czasopismo „Szkoła i Dom” redagował zespół Instytutu Wydawniczego „Nasza Księgarnia”, mieszczący się w Warszawie na ul. Smulikowskiego 4, następnie na Placu Dąbrowskiego 8. Wśród twórców pisma znaleźli się Henryk Garbowski, Elżbieta Jackiewiczowa, Aleksander Lewin, Jan Szurek. Od 1952 r. redakcję pisma objęła Natalia Obrębka. W zespole redakcyjnym była też prof. Lidia Wołoszynowa.

Pismo ukazywało się najpierw w formacie A5 $(24 \mathrm{~cm})$, następnie A4 $(29 \mathrm{~cm})$ w wersji czarno-białej. Jedynie umieszczone na okładce informacje wstępne były w kolorze szaro-niebieskim. Szata graficzna pisma pozostała niezmienna do 1952 r., z wyjątkiem numerów 10 i 11 z 1952 r., gdzie zamieszczono hasła bądź fragmenty programu Frontu Narodowego. Od pierwszego numeru w 1953 r. na okładce pojawia się ilustracja. W 1957 r. zwiększył się

12 B. Łu ka s z e w i c z, Prasa Olsztyna drugiej połowy XX stulecia, [w:] Olsztyn 1945-2005. Kultura i nauka, red. S. Achremczyk, W. Ogrodziński, Olsztyn 2006, s. 551-552.

13 A. Ko z i eł, Prasa w latach 1944-1989, [w:] Prasa, radio i telewizja w Polsce. Zarys dziejów, red., D. Grzelewska i in., Warszawa 1999, s. 126; M. C z y ż n i e w s k i, Propaganda polityczna władzy ludowej w Polsce 1944-1956, Toruń 2005, s. 112-123.

${ }_{14}$ M. C zyżniew s ki, Propaganda polityczna..., s. 116.

15 A. Os sows ka-Zw ie rzchow s ka, Wizerunek rodziców...

16 L.F., Po III Krajowym Zjeździe Korespondentów i Czytelników czasopisma „Szkoły i Domu”, „Szkoła i Dom” [dalej: SiD] 1956, nr 1, s. 3. 
nakład oraz format $(33 \mathrm{~cm})$ i wewnętrzna szata graficzna. Pismo zaczęto drukować techniką rotograwiurową (obustronną). Drukowaniem zajmowały się Zakłady Graficzne „Nasza Księgarnia”. Papier drukarski był klasy V, oznaczony symbolem B1/60 o zmiennej gramaturze. Pojedynczy egzemplarz miał objętość dwóch arkuszy drukarskich. Objętość pisma była raczej stała. Zazwyczaj pojedynczy egzemplarz zawierał 30-34 strony. Numery podwójne, które ukazywały się w miesiącach czerwiec-wrzesień nie przekraczały 70 stron.

Rozprowadzaniem pisma zajmowało się Państwowe Przedsiębiorstwo Kolportażu „Ruch”. Czasopismo można było prenumerować kwartalnie, półrocznie i rocznie. Cena jednego egzemplarza w latach 1949-1951 wynosiła 20 zł,

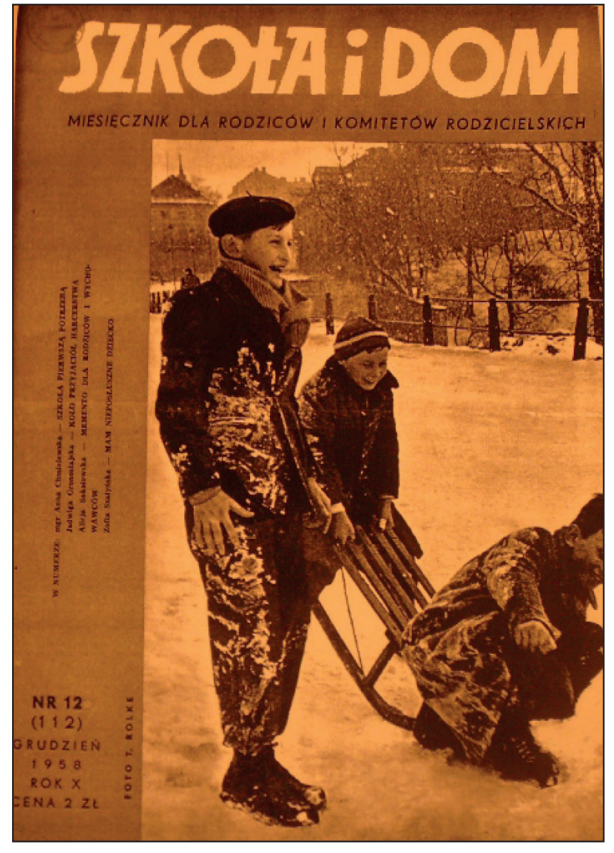

Fot. 2. Strona tytułowa ostatniego numeru miesięcznika „Szkoła i Dom” 1958, nr 12 Źródło: Warmińsko-Mazurska Biblioteka Pedagogiczna im. prof. T. Kotarbińskiego w Olsztynie w 1952 r. wzrosła do 60 zł, w 1953 do 80 zł, a w latach 1955-1958 wahała się od 1 do 2 zł. Trudno ustalić nakład pisma, ale $z$ wyjaśnień redakcji wynika, że kolportażem powinien się zająć każdy inspektorat szkolny ${ }^{17}$, stąd mniemam, że powinno ono być $w$ każdym przedszkolu, w szkole ogólnokształcącej stopnia podstawowego i licealnego czy szkole zawodowej podległej Ministerstwu Oświaty, gdyż w tych placówkach w lutym 1949 r. w ramach współpracy rodziców ze szkołą powołano komitety rodzicielskie ${ }^{18}$.

Biorąc pod uwagę strukturę czasopisma, do 1952 r. składało się na nią pięć stałych rubryk, tj. „Aktualne zagadnienia”; „W trosce o dziecko”; „Kronika”; „Czytelnicy piszą”; „Co czytać”. W 1952 r. miesięcznik "Szkoła i Dom” podwoił liczbę swoich rubryk stałych, stąd spis rzeczy był następujący: „Aktualne zagadnienia”; „W szkole”; „Wychowanie rodzinne”; "Pogadanka dla rodziców”; „Wychowanie pozalekcyjne”; „W trosce o zdrowie”; „Kronika”; „Czytelnicy piszą" (fot. 3); „Porady wychowawcze”; „Co czytać” ${ }^{19}$. Kolejna zmiana miała miejsce w styczniu 1955 r. Zmieniono układ pisma, jedynym stałym działem była

17 Rubryka „Czytelnicy piszą”: Redakcja, „Szkoła i Dom” leży w Inspektoratach, SiD 1949, nr 4, s. 29.

18 Zarządzenie Ministra Oświaty z dnia 26 lutego 1949 [...] o organizacji i zakresie działania Komitetów Rodzicielskich w przedszkolach, szkołach ogólnokształcących stopnia podstawowego i licealnego i szkołach zawodowych podległych Ministrowi Oświaty, Dz. U. MO 1949, nr 3, poz. 25.

19 Spis rzeczy, SiD 1952, nr 1, s. 2. 
rubryka „Czytelnicy piszą"20. Od 1957 r. nie publikowano spisu treści. Powstało wiele nowych działów, np. „Prawnik radzi”. We wszystkich przeanalizowanych przeze mnie egzemplarzach (93) rubryka ta nie pojawiła się w 24 numerach, w tym aż w ośmiu numerach z 1955 r.

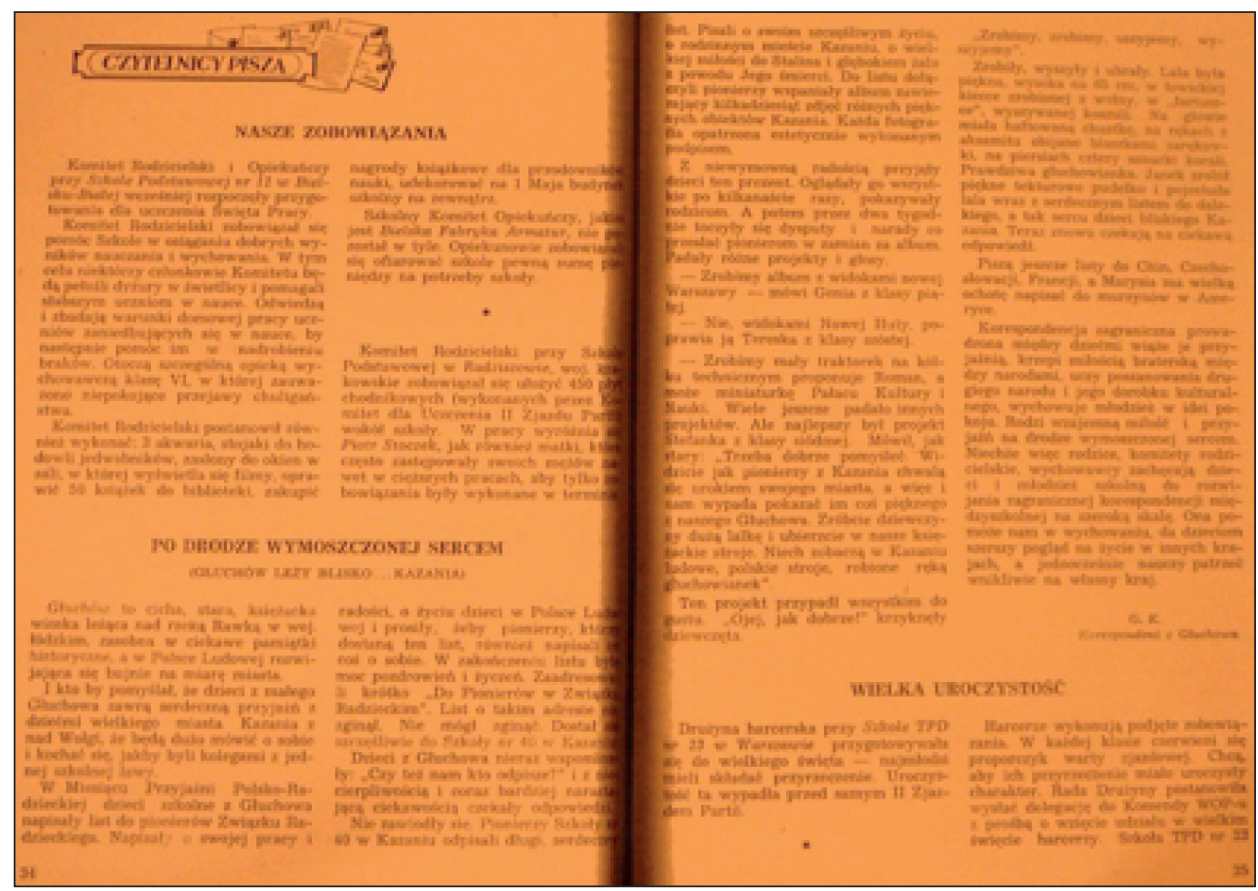

Fot. 3. Rubryka „Czytelnicy piszą”, „Szkoła i Dom” 1954, nr 5, s. 24-25

Źródło: Warmińsko-Mazurska Biblioteka Pedagogiczna im. prof. T. Kotarbińskiego w Olsztynie

Podstawową bazę źródłową stanowiło czasopismo „Szkoła i Dom”, które jest przechowywane w Warmińsko-Mazurskiej Bibliotece Pedagogicznej im. Tadeusza Kotarbińskiego w Olsztynie. W latach 1949-1958 ukazało się 112 numerów, z których przebadano 93. W okresie funkcjonowania pisma, na jego łamach ogłoszono 12 konkursów na różne tematy oraz dwa stałe konkursy dla osób prenumerujących i korespondentów ${ }^{21}$. W rubryce „Czytelnicy piszą” prezentowano fragmenty oraz streszczenia listów od rodziców, kierowników/dyrektorów szkół,

20 Treść, SiD 1955, nr 1, s. 21.

21 W numerze 3. (1956) redakcja ogłosiła „Stały konkurs na najlepszą korespondencję miesiąca”. Wśród wymagań uwzględniono: objętość wypowiedzi (do 5 stron maszynopisu), problematykę rozważań nad jednym konkretnym zagadnieniem (np. doświadczenia, trudności i osiągnięcia w pracy wychowawczej w szkole i w domu, współpraca rodziców ze szkołą, z drużyną harcerską, praca komitetów rodzicielskich i opiekuńczych). Autorzy dwóch najlepszych korespondencji miesiąca otrzymywali nagrody pieniężne: 1. nagroda - 150 zł, 2. nagroda - 100 zł. Redakcja, Stały konkurs na najlepszą korespondencję miesiąca, SiD 1956, nr 3, s. 20; Redakcja, Stały konkurs dla prenumerujących, SiD 1955, nr 7-8, s. 4; Redakcja, Stały konkurs na najlepszą korespondencję miesiąca, SiD 1957, nr 9, s. 14. 
członków komitetów rodzicielskich i opiekuńczych, uczniów, listy nie podpisane od osób prywatnych oraz listy korespondentów ${ }^{22}$. Za korespondentów należy uznać nieformalnych dziennikarzy z terenu, którzy zbierali informacje na potrzeby czasopisma. Przypuszczam, że (podobnie jak w innych pismach) korespondenci otrzymywali wynagrodzenie w postaci honorarium (fragment opublikowanej wypowiedzi: „Nasz korespondent z Gdyni, ob. Czesław Strzelec pisze: Prosiłbym bardzo, ażeby pieniądze za artykuły zostały przekazane w moim imieniu na «Budowę Warszawy». [...] O ile w przyszłości będzie mi się należało honorarium autorskie za nadesłane wiadomości, proszę od razu przekazać na budowę szkół w Warszawie"23) bądź prenumeraty. Redakcja miesięcznika „Szkoła i Dom” w numerze 8-9/1952 podała informację, że w najbliższych numerach wykorzysta nadesłaną korespondencję z terenu oraz wymieniła 10 nazwisk obywateli, którym bezpośrednio na łamach pisma odpowie na listy do redakcji ${ }^{24}$. O roli korespondentów w ówczesnej prasie, a także w czasopismach pedagogicznych świadczy zasada procedencji w adresowaniu treści życzeń z okazji przerwy wakacyjnej: „Wszystkim korespondentom, czytelnikom, nauczycielom, członkom komitetów rodzicielskich i opiekuńczych, rodzicom i dzieciom jak najlepszego wypoczynku w czasie wakacji, nabrania sił do jeszcze lepszej, ofiarniejszej pracy w nowym roku szkolnym życzy Redakcja «Szkoła i Dom»"25.

Biorąc pod uwagę dzieje listów publikowanych na łamach miesięcznika „Rodzina i Szkoła", należy wyodrębnić dwa okresy: 1949-1953/1954 i 1954/1955-1958. Pierwszy okres charakteryzuje się zainicjowaniem i rozwojem korespondencji prywatnej. Nadawca opublikowanego listu był znany z imienia i nazwiska oraz pełnionej funkcji. W latach 1954/1955-1958 w rubryce „Czytelnicy piszą” pojawiają się streszczenia listów czytelników, w mniejszym zakresie fragmenty ich korespondencji. Brakuje danych identyfikujących autorów listów, np. pełnionej funkcji czy tytułów listów.

Pewną trudność podczas analizy stanowi też brak informacji, kto zajmował się redagowaniem działu „Czytelnicy piszą"26. Ponadto listy nie są oznaczone czasowo, dlatego nie wiemy, czy korespondencja ukazywała się na bieżąco. W numerze 9/1957 w rubryce „Czytelnicy piszą” znalazł się podtytuł następującej

22 Redakcja czasopisma organizowała Krajowe Zjazdy Korespondentów i Czytelników, które gromadziły „Iudzi głęboko przejętych sprawami wychowania, świadomie szukających dróg doskonalenia pracy wychowawczej”. L.F., Po III Krajowym Zjeździe..., s. 1-4. Problematyka zjazdów dotyczyła spraw bezpośrednio związanych z rozwojem pisma oraz zagadnień dotyczących wychowania dzieci i młodzieży oraz poszukiwania sposobów przezwyciężania trudności. Niektóre wypowiedzi uczestników prezentowano na łamach czasopisma. Relację z pierwszego krajowego zjazdu korespondentów odnajdujemy w liście kierownika szkoły w Komornikach: „Cieszę się, że mogłem wziąć udział [...] Wśród wielu pomysłów, przedstawionych w czasie dyskusji, które mogą przyczynić się do zwiększenia popularności i poczytności tego pisma, z największą radością powitałem nowy dział [...] «Poradnik dla rodziców». Chcę wyrazić Redakcji wyrazy uznania za zapoczątkowanie tak interesującej i cennej współpracy z rodzicami”. A. Z a w i d z k i, Echa zjazdu korespondentów czasopisma „Szkoła i Dom”, SiD 1952, nr 1, s. 25.

${ }^{23}$ C. Strzele c, Na budowe Warszawy, tamże, nr 3, s. 28.

24 Redakcja, Odpowiadamy naszym czytelnikom i korespondentom, tamże, nr 8-9, s. 56.

25 Redakcja [bez tytułu], SiD 1954, nr 6 [4. strona okładki].

26 Redakcja, Czytelnicy piszą, SiD 1955, nr 1, s. 19. 
treści: „Opracowano na podstawie korespondencji nadesłanej w ub. roku szkolnym"27. Stąd też można sądzić, że nadsyłane do redakcji listy czekały na swoją publikację. Nie należy też wykluczyć, że listy w imieniu czytelników były pisane przez samych redaktorów miesięcznika „Szkoła i Dom”, co stanowiło zjawisko typowe dla tamtych czasów.

\section{Problematyka współdziałania szkoły z rodziną w świetle listów czytelników}

Przyjmuję, że współdziałanie to „uczestnictwo podmiotów, w tym przypadku rodziny ucznia i nauczycieli, w sytuacji zadaniowej, występujących wspólnie i z własnej woli oraz posiadających uświadomiony cel”, jakim jest dobro dziecka-ucznia ${ }^{28}$. Dwa podmioty, jakimi są rodzice i nauczyciele, stanowią zarazem „dwa różne i uzupełniające się środowiska wychowawcze"29. Dzięki dziecku/uczniowi środowiska te wchodzą we wzajemne relacje i „mają szereg wspólnych płaszczyzn działania"30.

Przedsięwzięcia te wyznaczała nowa polityka oświatowo-wychowawcza, sprowadzająca się do ukształtowania socjalistycznego modelu wychowania dzieci, przeciwstawnego modelowi wychowania tradycyjnego. Potępiając i wyśmiewając tradycyjną obyczajowość rodziny wiejskiej, propagowano wzór rodziny opartej na równouprawnieniu małżonków i „demokratycznych" stosunkach pomiędzy rodzicami a dziećmi ${ }^{31}$. W urzeczywistnieniu nowego modelu wychowania chodziło o ukształtowanie w dzieciach/uczniach „naukowego poglądu na świat”, propagowania norm moralności socjalistycznej czy socjalistycznych wzorców. Dla dziecka wzorem do naśladowania stawał się ojciec-przodownik bądź matka-przodownica, którzy ponosili odpowiedzialność wobec społeczeństwa za swoje potomstwo ${ }^{32}$. Ponieważ szkoła zajmowała się „produkowaniem” przyszłych pracowników, w związku z tym w domu rodzinnym sprawy życia zawodowego zyskiwały przewagę nad kwestiami rodzinnymi3 ${ }^{33}$. W nowym modelu wychowania dzieci praktykowano zbiorowe formy spędzania czasu wolnego. Poddawano kontroli instytucje zajmujące się wychowaniem dzieci. Kryterium klasowe wyznaczało sposób traktowania dzieci i ich rodziców. W różny sposób realizowano politykę ateizacji oświaty ${ }^{34}$.

27 Redakcja, Czytelnicy piszą, SiD 1957, nr 9, s. 14.

28 K. J a k u b i a k, Współdziałanie rodziny i szkoły w pedagogice /l Rzeczypospolitej, Bydgoszcz 1997 , s. 15.

${ }_{29}$ M. Ł o b o c ki, O współpracy nauczycieli i rodziców w rozumieniu tradycyjnym, [w:] Nauczyciele i rodzice. W poszukiwaniu nowych znaczeń i interpretacji współpracy, red. I. Nowosad, M. J. Szymański, Zielona Góra 2004, s. 87.

30 A. R a d z i wiłł, O współdziałaniu między szkołą a domem, Warszawa 1975, s. 4.

31 K. J a ku biak, Problematyka wychowania..., s. 214.

32 N. O brę b s ka, Wychowanie w rodzinie, Warszawa 1953, s. 4.

${ }_{33}$ F. Mielczarek, Dziecko jako przedmiot indoktrynacji w świetle analizy treści wybranych podręczników szkolnych z lat 1945-1956, [w:] Dziecko w społeczeństwie i rodzinie. Dzieje nowożytne, t. 2, red. K. Jakubiak, W. Jamrożak, Bydgoszcz 2002, s. 275.

34 D. J a r o s z, Polacy $i$ stalinizm 1948-1956, Warszawa 2000, s. 186-226. 
W okresie PRL próbowano stworzyć „rodzinę socjalistyczną”, gdyż takie pojęcie pojawiało się w języku oficjalnej propagandy. Nowy wzór rodziny socjalistycznej miał funkcjonować jako podstawowa komórka komunistycznego społeczeństwa. W związku z tym należało wpierw poddać przyspieszonemu procesowi „reedukacji” rodzinę tradycyjną. Proces reedukacji z jednej strony miał „wspierać”, a z drugiej ograniczać wpływy wychowawcze rodziny. W ten sposób ideologia komunistyczna ingerowała również w sferę prywatności rodziny, spychając ją do rangi wroga systemu ${ }^{35}$. Zaczęto popularyzować mit kontrdomu, czyli „instytucji i miejsc życia publicznego ważniejszych niż dom i rodzina"36. Stopniowo minimalizowano rolę rodziców i rodziny jako środowiska wychowawczego na rzecz nauczycieli i młodzieży ${ }^{37}$.

O ile w pierwszych latach powojennych związek rodziny ze szkołą opierał się na harmonii i współpracy, o tyle po 1948 r. relacje tych dwóch podmiotów cechowało upolitycznienie i zideologizowanie wymuszające podporządkowanie obszaru stosunków rodziny ze szkołą polityce oświatowej, władzy monopartii ${ }^{38}$. W związku z tym ustalono nowe cele wychowawcze, do których urzeczywistnienia starano się pozyskać rodziców ${ }^{39}$. W ramach świadczenia czynnej współpracy szkoły z domem władze oświatowe powołały następujące organizacje rodzicielskie:

- Sekcję Rodzicielską do Spraw Wczasów Letnich (1948);

- Komitety Rodzicielskie (KR) (1949) ${ }^{40}$

- Szkolne Komitety Opiekuńcze (KO) ${ }^{41}$

- Komisje Oświatowe przy Radach Narodowych ${ }^{42}$.

Aktywności rodziców w wymienionych organizacjach rodzicielskich, a zwłaszcza w komitetach rodzicielskich sprzyjały różnorodne formy współdziałania ${ }^{43}$. Wśród tradycyjnych form współpracy szkoły z domem i odwrotnie wyróżnia się:

${ }^{35}$ K. J a kubiak, Problematyka wychowania..., s. 212.

36 Tamże.

37 Tamże, s. 217.

${ }^{38}$ A. W. J a n ke, Współpraca rodziny i szkoły, [w:] Encyklopedia pedagogiczna XXI wieku, t. 7, red. nauk. T. Pilch, Warszawa 2008, s. 296-297.

${ }^{39}$ R. G r z y b o w s k i, Pedagogizacja rodziny jako próba włączenia jej do procesu laicyzacji wychowania dzieci i młodzieży w PRL, [w:] Orientacje i kierunki w badaniach historyczno-pedagogicznych, red. I. Michalska, G. Michalski, Łódź 2009, s. 128-130.

40 Zarządzenie Ministra Oświaty z dnia 26 lutego 1949...

${ }^{41}$ Szkolne Komitety Opiekuńcze powstawały z inicjatywy partii politycznych i organizacji społecznych w zakładach pracy, fabrykach, majątkach państwowych i spółdzielniach wiejskich, współpracowały z komitetami rodzicielskimi. Komunikat w sprawie Szkolnych Komitetów Opiekuńczych, Dz. U. MO, 1949, nr 3, poz. 45.

42 Do zakresu działań Komisji Oświatowych należało m.in. współdziałanie i nadzór nad Komitetami Szkolnymi, czuwanie nad wykonywaniem powszechności nauczania (np. rozpatrywanie wniosków kierowników szkół o ukaranie rodziców za niewypełnienie przez dzieci obowiązku szkolnego i dopilnowanie wyegzekwowania nałożonych kar przez właściwą gminę). Plan pracy na rok szkolny 1949/50 Inspektoratu Szkolnego w Węgorzewie, APO, zespół: KOS, sygn. 495/31, k. 247-248.

${ }^{43} \mathrm{~W}$ literaturze przedmiotu można znaleźć podział na różnorodne tradycyjne oraz innowacyjne formy współpracy szkoły z rodziną, a wśród nich - formy wiodące, uzupełniające i wspierające. Zob. E. Z y zik, Tradycyjne i innowacyjne formy współpracy szkoły z rodzicami, „Nauczanie Początkowe” 2009/2010, nr 2, s. 61-66. 
- wzajemne odwiedzanie się (wizyty wychowawców w domach swych wychowanków i hospitacje rodziców w zakresie różnych dziedzin i form pracy szkoły);

- wywiadówki;

- specjalne zebrania rodziców (ogólne, dla wszystkich rodziców, i specjalistyczne, z udziałem pewnych kategorii rodziców);

- dzienniczek ucznia;

- kolportaż materiałów propagandowych i korespondencja;

- wszelkie formy doraźnych kontaktów rodziców ze szkołą44.

Duże możliwości popularyzacji wiedzy na temat współpracy szkoły z rodziną miało czasopismo „Szkoła i Dom”. Było to jedyne pismo, jak twierdził Stanisław Dobosiewicz, Dyrektor Departamentu MO, które w szerokim zakresie prowadziło akcję zbliżania szkoły z rodziną ${ }^{45}$. Tytuł periodyku wskazywał na pierwszorzędną rolę środowiska szkolnego w realizowaniu ideałów wychowawczych PRL.

Na podstawie listów publikowanych w miesięczniku „Szkoła i Dom” można dokonać analizy problemu dotyczącego współdziałania szkoły z rodzicami w latach 1949-1958 w następujących obszarach: powstanie komitetów rodzicielskich i ich rozwój poprzez realizację działań w zakresie nauczania i wychowania, rozpoznania i zaspokajania potrzeb szkoły, współudział w organizowaniu uroczystości szkolnych, wycieczek itp., dbałość o zaspokajanie potrzeb gospodarczych i sanitarnych szkół. Zakres współpracy szkoły z rodziną regulował Regulamin Komitetów Rodzicielskich ${ }^{46}$, który decydował też o formie współdziałania.

Zgodnie z Regulaminem Komitetów Rodzicielskich, współpraca wychowawcza z nauczycielami miała przede wszystkim opierać się na harmonijnym współdziałaniu szkoły i domu, a zwłaszcza na stałym zaznajamianiu się z pracą i potrzebami szkoły. To zaznajamianie się odbywało się za pośrednictwem bezpośrednich kontaktów szkoły z rodziną ${ }^{47}$.

Szczególnie popularną i często popularyzowaną na łamach czasopisma "Szkoła i Dom" formą współpracy były zebrania rodziców, zarówno ogólne, dla wszystkich rodziców bądź członków organizacji rodzicielskich, jak i specjalistyczne, przeznaczone dla pewnych kategorii rodziców. W zależności od kategorii rodziców zebrania odbywały się cyklicznie - semestralnie dla ogółu rodziców i miesięcznie dla członków KR. Zebrania KR miały swój określony porządek obrad i charakter, co zostało zauważone m.in. przez członka KR ze szkoły podstawowej w Grudziądzu, który pisał:

Zebrania [...] cieszą się zawsze dużą frekwencją. Jest to znak, że rodzice współpracując z kierownictwem szkoły, interesują się nauką i wychowaniem swych dzieci. [...] Na jednym z ostatnich zebrań Komitetu Rodzicielskiego wystąpili w części artystycznej mali artyści - dzieci tejże szkoły w barwnych tańcach ludowych ${ }^{48}$.

${ }^{44}$ F. Ko wa le w s ki, Wychowawcza i społeczna działalność szkoły w środowisku, WarszawaPoznań 1976, s. 124-125.

45 S. D o b o s i e w i c z, [bez tytułu], SiD 1954, nr 12, s. wew. okładki.

46 Zarządzenie Ministra Oświaty z dnia 26 lutego 1949...

47 A. R a d z i w iłł, O współdziałaniu..., s. 141.

48 A. O I ki e wi c z, Zgodna współpraca, SiD 1951, nr 4, s. 28. 
Czytelnicy w listach do redakcji, podejmując problem organizacji zebrań KR, zwracali uwagę na takie kwestie, jak: staranność w przygotowaniu zebrań, dbałość o frekwencję rodziców ${ }^{49}$, ich zaangażowanie w przebieg zebrań poprzez wygłaszanie pogadanek ${ }^{50}$ czy udział w dyskusji. Istotnym elementem zebrań były dyskusje, podczas których - jak podkreśla członek Komisji Propagandowej KR w Gościszewie - „krytycznie i samokrytycznie oceniamy naszą pracę, aby coraz mniej popełniać błędów" ${ }^{\prime 1}$. Kontynuując ten wątek, na łamach czasopisma opublikowano list czytelnika, który udzielał rad, jak przygotować wyborcze zebranie komitetu rodzicielskiego w ramach akcji wyborów do Sejmu. Autor listu tak wypowiadał się w tej sprawie:

Komitet Rodzicielski powinien zwołać zebranie, jak najliczniej zgromadzić rodziców i omówić z nimi naszą ordynację wyborczą, nasze zdobycze. Aktyw rodziców powinien [...] dobrze obmyśleć i zebrać argumenty, które powinny być dostosowane do środowiska życia wsi. [...] mówić na zebraniach i jednocześnie pokazywać nasze dotychczasowe osiągnięcia, podawać realne przykłady z najbliższego otoczenia. [...] Członkowie Komitetu Rodzicielskiego winni [...] rozmawiać również ze swoimi sąsiadami, znajomymi i w rozmowie z każdym człowiekiem mówić, jak wielkim wydarzeniem politycznym są wybory"52.

W kolejnym z listów przedstawiono wypowiedź dotyczącą łamania prawa przy wyborach do KR. Anonimowy czytelnik, opisując zdarzenie, zwrócił się więc z prośbą do redakcji o „konkretną odpowiedź”. Była ona następująca:

Stanowisko naszego czytelnika jest zupełnie słuszne. Członków komitetu rodzicielskiego powinni wybrać rodzice drogą głosowania. Sprawę przekazujemy Komisji Oświaty i Kultury przy PRN w Kole - do wiadomości i załatwienia ${ }^{53}$.

Przykład specjalistycznego zebrania przeznaczonego dla pewnych kategorii rodziców odnajdujemy w liście czytelnika ze SP nr 2 w Tuszynie. Autor listu, relacjonując problem chuligaństwa w szkole, zwraca uwagę na podjęte działania, wymierzone w bumelantów, wagarowiczów i przywódców łobuzerskich szajek. Jednym z nich było zwołanie specjalnego zebrania wszystkich rodziców wagarujących uczniów. Jak zauważa korespondent - „Na zebraniu tym rodzice z przerażeniem dowiedzieli się od wychowawców i Komitetu Rodzicielskiego o wyczynach swych dzieci" ${ }^{54}$.

Oprócz zebrań do tradycyjnych form współpracy rodziców ze szkołą należą hospitacje w zakresie różnych dziedzin i form pracy szkoły. Z listów do redakcji

49 H. Ku le ta, Czytelnicy piszą, SiD 1956, nr 12, s. 19.

${ }^{50}$ W Szkole Podstawowej nr 8 w Warszawie na zebraniach KR w 1952 r. odbyły się pogadanki na następujące tematy: Współpraca rodziców ze szkołą; Walka z chuligaństwem na terenie $i$ poza szkołą; Program wychowania i nauczania; Higiena w szkole i w domu; Dyscyplina w szkole i w domu; Frekwencja i regulamin uczniowski; Politechnizacja; J. Ka c p r zak, Dobre wychowanie dzieci-patriotyzm obowiązkiem rodziców, SiD 1953, nr 10, s. 30.

51 L. Siele n i e wi c z, Razem z gromadą, tamże, nr 2, s. 29.

52 P. U r b a n e k, Jak należy przygotować wyborcze zebrania rodzicielskie, SiD 1952, nr 10, s. 32.

53 Redakcja, Czy tak się przeprowadza wybory?, tamże, nr 12, s. 28.

${ }^{54}$ M.Cz, Zwalczyliśmy wagary i bumelanctwo, SiD 1954, nr 2, s. 36. 
wynika, że rodzice zrzeszeni w KR odwiedzali szkoły, najczęściej prowadząc hospitacje lekcji, co potwierdza poniższy fragment:

Rodzice często odwiedzają lekcje. W pierwszym półroczu szkolnym 97 lekcji, a w drugim znacznie więcej, szczególnie w klasach szóstych i siódmych, biorąc pod uwagę to, że w klasach tych młodzież zdawała egzaminy ${ }^{55}$.

W epoce stalinowskiej szczególnym rodzajem zebrań były narady. W szkołach praktykowano narady produkcyjne, zamiennie określane też jako narady wytwórcze. W przeciwieństwie do składu Rady Pedagogicznej, w skład narady wchodzili, oprócz nauczycieli, rodzice, uczniowie, a nawet działacze ZMP, aktywiści partyjni. Zgodnie z założeniem szkoły, narady opierały się na wprowadzaniu w życie dyscypliny socjalistycznej, stąd kładziono nacisk na akcję propagandową, dyscyplinę ${ }^{56}$. Również do redakcji „Szkoły i Domu” przychodziły listy, zwłaszcza od nauczycieli, którzy relacjonowali przebieg narad tzw. trójek z rad klasowych. Trójki z rad klasowych spotykały się raz w miesiącu z nauczycielem w celu omówienia zagadnień wychowawczych. Spotkania te określano mianem narad, które „kończyły się podjęciem właściwych wniosków czy decyzji” ${ }^{57}$. W innym liście czytelnik informuje: „Na miesięcznych naradach wytwórczych członkowie Komitetu Rodzicielskiego wraz z niestrudzonym w pracy kierownictwem szkoły omawiają i wytyczają pracę poszczególnym sekcjom"58.

Jak wynika z analizy korespondencji, w niektórych szkołach inspiracją do zwoływania narad czy zebrań stało się analizowane czasopismo, co potwierdza list nauczycielki z powiatu bytowskiego:

Otrzymując czasopismo „Szkoła i Dom” zwołuję co miesiąc komitet rodzicielski na zebranie szkoły. Opierając się na tym piśmie, wygłosiłam referat pt. „Współpraca domu ze szkołą” i pogadanki na różne tematy. Zapoznałam również Komitet Rodzicielski z tym pismem ${ }^{59}$.

Czasopismo „Szkoła i Dom” było też przedmiotem dyskusji wielu zebrań komitetów rodzicielskich (np. w Szkole Podstawowej w Wagowie dyskutowano „nad walorami czasopisma «Szkoła i Dom» względnie nad ulepszeniem tego czasopisma i jego uzupełnieniem w pewnych dziedzinach. Mamy nadzieję, że nawiąże się wkrótce stały kontakt z redakcją" $\left.{ }^{60}\right)$. Odgrywało również istotną rolę w zakresie samokształcenia ideologicznego członków komitetów rodzicielskich:

Pismo „Szkoła i Dom” oddaje mi nieocenione usługi w pracy społecznej, w dokształcaniu ideologicznym nowo obranego Komitetu Rodzicielskiego. Uchwaliliśmy, aby czasopismo to w porządku alfabetycznym docierało do każdego rodzica [...], z tym zastrzeżeniem, że musi ono być przeczytane w48 godzinach i natychmiast doręczone następnemu czytelnikowi wymienionemu w kurendzie obiegowej ${ }^{61}$.

55 R. Melle ro wa, Rodzice dziękują nauczycielom, SiD 1953, nr 8-9, s. 47.

56 K. Kosiński, O nową mentalność. Życie codzienne w szkołach 1945-1956, Warszawa 2000, s. $125-126$.

57 K. Grondkow s k i, Rodzicielskie zespoły, SiD 1957, nr 9, s. 16.

58 R. Melle rowa, Rodzice..., s. 47-48.

59 K. L in ke, O zadaniach domowych, SiD 1957, nr 7-8, s. 31.

60 A. Z a w i d z k i, „Szkoła i Dom” pomaga w pracy, SiD 1951, nr 3, s. 28.

61 Tamże. 
Poprzez wybrane fragmenty korespondencji przekazywano treści propagandowe, zwracając uwagę czytelników na właściwe postawy rodziców. Jako przykład zacytuję dłuższy fragment wybranego przez Redakcję listu dwóch matek ze szkoły podstawowej, dotyczącego sprawozdania z wyborów do komitetów rodzicielskich. Redakcja argumentowała w następujący sposób: „Wybory do Komitetów Rodzicielskich w naszych szkołach już się odbyły. Sprawozdanie z zebrania wyborczego w szkole nr 12 w Bytomiu ze względu na ciekawy jego przebieg i właściwą postawę rodziców oraz kierownictwa zamieszczamy"62. W sprawozdaniu tym korespondentki napisały:

Komitet współpracował wydatnie i zgodnie z kierownictwem szkoły, z gronem nauczycielskim i starszą dziatwą w sposób planowy, systematyczny i zespołowy. Współpraca ta polegała na zdobywaniu funduszów przez urządzanie imprez, zaspokajanie potrzeb materialnych, pomoc w uzyskaniu dobrej frekwencji (wywiady), pomoc w sporządzaniu pomocy naukowych, zasilaniu biblioteki w książki, na pracy w związku z akcją letnią (rozprowadzanie i zaopiniowanie kart dziecka). Opieka szkolna zaś opiekowała się w szczególny sposób półsierotami, zaopatrując je w obuwie. [...] W skład komitetu weszło 34 osób, w tym 50\% robotników, 30\% pracowników umysłowych, inni - 20\%, mężczyzn 11 , kobiet 23. [...] kierowniczka szkoły wręczyła siedmiu osobom z Komitetu Rodzicielskiego - aktywistom pracy - pisemne podziękowanie ${ }^{63}$.

Z kolei z listu od czytelnika z Katowic, który również ma formę sprawozdania, dowiadujemy się o przebiegu narady aktywu rodzicielskiego szkół i przedszkoli TPD, której jednym z celów była „wymiana doświadczeń zdobytych przez komitety rodzicielskie"64.

Na rozwój bezpośrednich kontaktów szkoły z rodziną szczególny wpływ miał nauczyciel. Świadczy o tym liczba opublikowanych listów do redakcji, a także ich problematyka. Najczęściej nauczyciele pisali o organizacji komitetów rodzicielskich, a także ich funkcjonowaniu. Nauczyciel ze Szkoły Podstawowej w Radzionkowie donosił:

Komitet Rodzicielski ma w naszej szkole dużo pracy. [...] postanowił zorganizować szereg zebrań, konferencji rodzicielskich, wygłoszone będą referaty z dziedziny wychowania oraz zagadnień polityki naszej - jak „Plan 6-letni”, „Walka o pokój”, „Socjalizacja wsi” itp. Dobrze zorganizowana praca Komitetu Rodzicielskiego w naszej szkole jest wielką pomocą dla nauczycieli. Nie czują się oni odosobnieni w swej pracy. Z drugiej zaś strony rodzice widzą, że sprawa frekwencji, wychowania i wyników nauczania nie jest tylko sprawą nauczyciela, ale jest to sprawa ogólna - wspólna sprawa całego społeczeństwa ${ }^{65}$.

Oprócz wymienionych zagadnień, podczas zebrań komitetów rodzicielskich z nauczycielami w przedszkolach ważna była kwestia „wychowania socjalistycznego w przedszkolu”66, zaś w szkole podstawowej - „ciekawe fragmenty z dziedziny ideologicznej i z zagadnień wychowawczych"67.

\footnotetext{
62 Redakcja, Dla dobra dziatwy szkolnej, SiD 1951, nr 3, s. 29.

63 Tamże.

${ }^{64}$ F. B y t o m s k i, Czytelnicy piszą, SiD 1956, nr 12, s. 19.

65 F. Tor oń, Na nowej drodze, SiD 1951, nr 4, s. 29.

66 J. U r b a ń c z y k, Dobrze pracujące komitety rodzicielskie w przedszkolach cieszyńskich, SiD

67 A. Z a wi d z k i, „Szkoła i Dom”..., s. 28.
} 1953, nr 8-9, s. 46. 
Nauczyciele-korespondenci słali do czasopisma wyrazy wdzięczności dla konkretnych komitetów rodzicielskich ${ }^{68}$. Redakcja publikowała sporo listów od kierowników szkół, nauczycieli, wychowawców, którzy zwracali się z prośbą o umieszczenie na łamach pisma „słów uznania i wdzięczności dla Komitetów Rodzicielskich za ofiarną pracę, za okazaną nauczycielowi pomoc na wszystkich odcinkach życia społecznego" ${ }^{\prime \prime}$. W związku z powyższym redakcja od numeru 5/1952 wprowadziła rubrykę „Wzorcowo pracujące Komitety”, w której umieszczano takie informacje jak: nazwę komitetu, krótką notatkę o jego osiągnięciach, nazwiska najbardziej wyróżniających się członków $\mathrm{KR}^{70}$. W numerach 5-7/1952 w specjalnie wyszczególnionej rubryce zaprezentowano 24 przykłady wzorcowo pracujących $\mathrm{KR}^{71}$. Z czasem dział „Czytelnicy piszą” zdominowała problematyka prezentacji osiągnięć KR. Czytelnicy informowali o różnych formach pożytecznej pracy społecznej aktywu rodzicielskiego, jak np. organizowaniu imprez artystycznych i pomocy finansowej, podejmowaniu się remontów ${ }^{72}$. Jak podkreślali, współpraca rodziców ze szkołą dotyczyła „zarówno spraw wychowawczych, jak i gospodarczych"73. Nauczyciele przybliżali osiągnięcia komitetów rodzicielskich, „aby pobudzić i zachęcić do coraz lepszej pracy i współzawodnictwa wszystkie komitety rodzicielskie, aby podobnie jak nasz mogły otrzymać zaszczytne miano przodującego"74. O zasługach dla członków komitetów rodzicielskich pisali też uczniowie, którzy na łamach pisma składali podziękowania za „tak wielką troskę o nas" ${ }^{\prime \prime}$. Szczególną uwagę zwracali na zasługi rodziców, zwłaszcza matek, należących do aktywu opieki klasowej ${ }^{76}$.

O zaangażowaniu rodziców w życie szkoły świadczy m.in. korespondencja nauczyciela, który zachęcał do wygłaszania „szereg[u] referatów z zakresu wychowania młodzieży" 77 w ramach szkolenia pedagogicznego, mającego na celu podniesienie czytelnictwa książek pedagogicznych wśród rodziców. Inni nauczyciele apelowali do rodziców o aktywność „w pracy kół przyjaciół harcerstwa, o pomoc doświadczonych rodziców w organizowaniu zajęć drużyn i w zakupie konieczne-

68 W numerze 4. z 1952 r. na łamach czasopisma opublikowano list czytelnika wypowiadającego się w sprawie pracy komitetów rodzicielskich. Czytelnik pisał: „W czasie wyjazdów w teren spotykam tu i ówdzie dobrze pracujące Komitety Rodzicielskie. Jednym z nich jest Komitet Rodzicielski przy Szkole Podstawowej w Woli Książęcej koło Poznania. Członkowie tego Komitetu nie tylko zachęcali chłopów w swojej gromadzie do budowy szkoły, ale stale pomagają kierownictwu szkoły w trudnej pracy wychowawczej. Często bywają w szkole, odwiedzają lekcje, interesują się stopniami i zachowaniem dzieci. potem razem z nauczycielem obmyślają różne sposoby: jak pomóc dzieciom, które mają złe warunki materialne, jak zachęcać do pracy tych, którym nauka z trudem przychodzi, jak pomóc w odrabianiu lekcji”. T. To m k i e w i c z z Warszawy, Dawniej i dziś, SiD 1952, nr 4, s. 29.

69 Dobrze pracujące komitety rodzicielskie, SiD 1950, nr 8-9, s. 42-43.

70 Redakcja, Pracujemy dla dobra młodzieży. Wzorowo pracujące Komitety, SiD 1952, nr 5, s. 29.

71 Tamże, s. 29-30; nr 6, s. 29; nr 7, s. 28.

72 Czytelnicy piszą, SiD 1957, nr 4, s. 19.

73 Tamże, nr 7-8, s. 39.

${ }^{74}$ Grono Nauczycielskie SP nr 4 w Stargardzie Gdańskim, Dobrą pracą cementujemy jedność narodu, SiD 1952, nr 12, s. 29.

75 K. S te fań s k i, Dziękujemy rodzicom, SiD 1953, nr 3, s. 31.

76 Uczennica kl. VIla SP nr 27 w Poznaniu, Młodzież szkolna razem z rodzicami, tamże, nr 5, s. 30.

77 A. Z a w i d z k i, Rodzice uczą się, SiD 1952, nr 7, s. 27; F. J e s i o n o w s k i, Dziękujemy Polsce Ludowej za piękną szkołę, SiD 1954, nr 10, s. 36. 
go sprzętu"78. Szczególnie podkreślali zaangażowanie rodziców w kolektywizację wsi, m.in. poprzez rozmowy „z dziećmi o swej pracy na roli, o podnoszeniu plonów z hektara, o wypełnianiu swych obowiązków wobec państwa" ${ }^{29}$. O udziale aktywu rodzicielskiego w pracy społecznej na wsi pisał do „Szkoły i Domu” kierownik jednej ze szkół w powiecie hrubieszowskim:

Komitet rodzicielski ma również duże zasługi w upowszechnianiu wiedzy rolniczej. [...] W okresie zimowym nauczyciele i rodzice, wspólnie z dziećmi i młodzieżą dorosłą organizują przedstawienia. Z przygotowaną sztuką objeżdżamy okoliczne wsi, krzewiąc w ten sposób kulturę ${ }^{80}$.

W innym liście kierownik SP w Suchostrudze obszernie opisał akcję obowiązkowych dostaw dla państwa. Szczególne wyróżnił nauczycieli i członków KR - aktywistów tej akcji ${ }^{81}$.

Na łamach działu „Czytelnicy piszą” nauczyciele niejednokrotnie przypominali o obowiązkach komitetów rodzicielskich. Oprócz wsparcia w zradiofonizowaniu szkoły, KR powinien opiekować się sprzętem radiowym, tak, „aby radio szkolne znajdowało się w należytym stanie, było stale zdatne do użytku"82. Zdarzały się też listy, w których czytelnicy utyskiwali na małe zainteresowanie rodziców współpracą ze szkołą: „Bolączką [...] jest mała aktywność niektórych członków komitetu rodzicielskiego i anemiczna dzielność kilku rad klasowych"83. W innych opisywali, jak za sprawą czasopisma „Szkoła i Dom” ich relacje z rodzicami ulegały wyraźniej poprawie, co potwierdza list kierownika szkoły w Zembrzu, w powiecie brodnickim:

Obecnie każde dziecko otrzymuje pismo dla swoich rodziców. Od czasu gdy rodzice czytają pismo, coraz więcej interesują się szkołą i dziećmi. Coraz częściej przychodzą do szkoły i proszą o radę w wychowaniu dzieci. interesują się o wiele więcej sprawami gospodarczymi szkoły ${ }^{84}$.

Zgodnie z koncepcją socjalistycznego wychowania dzieci i młodzieży, szkoła i dom miały czuwać nad demokratycznym kierunkiem ich wychowania. $\mathrm{Na}$ łamach czasopisma publikowano wypowiedzi czytelników w sprawach wychowania młodzieży.

Komitety rodzicielskie miały realizować działania w zakresie nauczania i wychowania. W związku z tym sporo listów do miesięcznika „Szkoła i Dom” podejmowało problem uczestnictwa rodziców w zorganizowaniu systematycznego uczęszczania dzieci do szkół. Jak wynika z ustaleń redakcji, „Na wielkie znaczenie domu rodzinnego i jego wpływu na wychowanie dzieci” zwracało uwagę wielu czytelników ${ }^{85}$. Najczęściej autorzy listów opisywali takie działania, jak np. zorganizowanie stałych dyżurów wychowawczych rodziców, otwieranie Gabinetów Komitetu

78 J. Derecki, Czytelnicy piszą, SiD 1957, nr 9, s. 15.

79 Z. S i w c z y ń s ka, Dobrze pracuje się z takimi rodzicami, SiD 1953, nr 3, s. 31.

80 Z. B a rań s k i, Czytelnicy piszą, SiD 1956, nr 7-8, s. 39.

81 T. Ku rp ie w s ki, Komitet Rodzicielski pomaga w skupie zboża, SiD 1954, nr 9, s. $28-29$.

82 N. J ę d rzej c z y k, O wykorzystaniu w szkole audycji radiowych, SiD 1957, nr 2, s. 15.

83 J. Gruch ała, Czytelnicy piszą, SiD 1956, nr 4, s. 19.

${ }^{84}$ K. Błas z kie wi c z, Rodzice lepiej pracują, SiD 1952, nr 3, s. 28.

85 Redakcja, Czytelnicy piszą, SiD 1956, nr 9, s. 15. 
Rodzicielskiego, co miało miejsce w jednej ze szkół podstawowych w Szczecinie. W Gabinecie dyżurowali członkowie komisji naukowo-wychowawczej oraz rodzice, którzy zajmowali się udzielaniem „porad i pomocy uczniom słabszym w nauce [...]. W gabinecie tym uruchomiono także czytelnię dla rodziców oraz rozdzielnię czasopisma "Szkoła i Dom»" ${ }^{86}$. W celu uściślenia współpracy z nauczycielem komitety rodzicielskie pracowały nad „uświadamianiem rodziców o konieczności regularnego posyłania dzieci do szkoły, wdrażania ich do systematycznej nauki, do starannego odrabiania zadań domowych"87, upowszechnianiem i przestrzeganiem regulaminu uczniowskiego, będącego „narzędziem pracy wychowawczej z dziećmi dla szkoły i dla rodziców”88 czy organizacją gabloty, „którą umieścimy na widocznym miejscu i tam będziemy umieszczać każdorazowo, przy większym zebraniu rodziców, specjalną gazetkę, komunikaty itp."89.

W kwestii wychowania dzieci nadawcy listów najczęściej zwracali uwagę na organizowanie opieki. Rodzice w tym zakresie szczególnie wymieniali takie jej formy, jak: opieka nad świetlicą ${ }^{90}$, opieka nad dziećmi w czasie wolnym od zajęć szkolnych (np. „Doskonała kuchnia i wytworne kierownictwo kolonii, która prowadziła nauczycielka Danuta Molska z Łodzi, spełniły swoje zadanie"91). Ponadto autorzy listów prezentowali KR, które troszczyły się o uczniów słabych i zaniedbanych, prowadziły dożywianie ${ }^{92}$, organizowały opiekę nad dziećmi podczas wakacji czy wycieczek szkolnych ${ }^{93}$.

W listach pojawiają się też zagadnienia dotyczące trudności w wychowaniu dzieci i młodzieży. Na niewłaściwe zachowanie się młodzieży w miejscach publicznych zwrócił uwagę autor listu z numeru 2/195294. Jedna z członkiń sekcji naukowo-wychowawczej ${ }^{95} \mathrm{KR}$ w Świdrze zastanawiała się, gdzie jest granica dopuszczająca młodzież do kina na niedozwolone filmy:

[...] o ile jedne filmy mogą mieć na rozwój dziecka wybitnie dodatni wpływ, to istnieje szereg zasadniczych powodów, by innych filmów młodzieży nie pokazywać [...] należałoby wprowadzić jeden seans młodzieżowy do wszystkich kin (np. dni powszednie godz. 15, niedziela godz. 12), lub stworzyć specjalne kina dla młodzieży ${ }^{96}$.

\footnotetext{
86 J. B e h n ke, Szczecin, tamże, nr 2, s. 19.

87 Redakcja, Czytelnicy piszą, SiD 1955, nr 3, s. 19.

88 J. Ka rd a c h, O współpracy domu ze szkołą, SiD 1958, nr 10, s. 15.

89 A. M i c o r e k, Gazetka Komitetu Rodzicielskiego, SiD 1952, nr 11, s. 31.

90 K.G., W wiejskiej świetlicy, SiD 1951, nr 4, s. 28-29.

91 K. Ga s e k, Na koloniach, SiD 1958, nr 9, s. 15.

92 A. Wa c h ta r c z y k, Z dużym poczuciem odpowiedzialności, SiD 1953, nr 5, s. 30.

93 Redakcja, Czytelnicy piszą, SiD 1955, nr 10, s. 15.

94 F. N o w a k, Zachowanie się dziecka na ulicy, SiD 1950, nr 2, s. 31.

95 W latach szkolnych 1949/50-1953/54 KR powoływał takie komisje jak: naukowo-wychowaw-
} cza, finansowa, dożywiania, wczasów, gospodarcza, kulturalno-rozrywkowa (Zarządzenie Ministra Oświaty z dnia 26 lutego 1949...). Od 1954 r. w ramach KR powoływano w miarę potrzeby spośród członków i rad klasowych komisje takie jak: naukowo-wychowawcza, szerzenia wiedzy pedagogicznej wśród rodziców, kulturalno-rozrywkowa, sanitarno-gospodarcza, dożywiania, wczasów itp. (Regulamin Komitetów Rodzicielskich w przedszkolach, szkołach ogólnokształcących i szkołach zawodowych podległych Ministrowi Oświaty, [w:] Zarządzenie Ministra Oświaty z 7 października 1954 r. w sprawie komitetów rodzicielskich, Dz. U. MO 1954, nr 14, poz. 115).

96 J. Vi w e g e r, O filmach dla młodzieży niedozwolonych, SiD 1950, nr 6-7, s. 53-55. 
Inna autorka listu zwracała się do członków KR i matek z prośbą o udział w dyskusji w sprawie zwalczanie plagi, jaką są wulgaryzmy w języku polskim wśród dzieci i młodzieży ${ }^{97}$.

Biorąc pod uwagę założenia stalinowskiej koncepcji wychowania, należy podkreślić propagowanie w prasie „egzempli” rodziców, nie tylko jako przodowników i aktywnych członków komitetów rodzicielskich (których „pracy szkoła zawdzięcza w dużej mierze uświadomienie rodziców, ich przyjazny stosunek do szkoły, ich pomoc w wychowaniu dzieci”98), ale także jako bumelantów. Czasopismo „Szkoła i Dom" prezentowało sylwetki rodziców, z których nie należy brać przykładu. Przedmiotem do dyskusji na łamach pisma stał się opis zachowania ojca, który nie przestrzegał zasad praworządności w szkole ${ }^{99}$.

W związku z powrotem religii do szkół na łamach pisma opublikowano długi list N. Dziewanowskiej, która zaniepokojona przykładami nietolerancji osób wierzących w stosunku do ateistów, apelowała do redakcji o serdeczny artykuł: „do rodziców wierzących i katolików, aby wpłynęli na dzieci, tak, aby nie dokuczały one kolegom niewierzącym, żeby zachowywały się z miłością do bliźniego"100.

Spośród stale pojawiających się wypowiedzi czytelników szczególnie akcentowano kwestię edukacji domowej uczniów. Nauczyciele jako nadawcy listów podkreślali rolę rodziców w organizowaniu warunków do wykonywania pracy domowej dzieci oraz podejmowania przez nich działań kontrolnych „w sposób uzgodniony z nauczycielem"101. Rodzice zaś zwracali się z prośbą do nauczycieli o „uważne przeglądanie zeszytów uczniowskich” w celu uniknięcia np. błędów ortograficznych ${ }^{102}$.

Istotnym elementem środowiska szkolnego i rodzinnego dotyczącym edukacji domowej uczniów/dzieci była nieustanna kontrola, która wynikała z wprowadzenia Ustawy o zabezpieczeniu socjalistycznej dyscypliny pracy z 19 kwietnia 1950 r. ${ }^{103}$ Nowa ustawa pociągała za sobą szereg niestosowanych w szkolnictwie rygorów. Szczególną rolę w kontrolowaniu postępów uczniów odgrywały dzienniczki ucznia oraz inne formy dokumentacji, o czym świadczą wypowiedzi listowne zarówno nauczycieli ${ }^{104}$, jak i rodziców. Na przykład w liście członka KR przy SP w Mszadli Nowej czytamy: „Komitet Rodzicielski postanowił wzmóc kontrolę nad wykonywaniem prac domowych - przez codzienne przeglądanie dzienniczków uczniow-

97 J. U r ba n o w a, W obronie czystości naszej pięknej mowy, SiD 1954, nr 2, s. 34.
98 S. C w e n a r, O ludziach z podgórskiej wsi, tamże, s. 33-34.
99 J. Zi e li ń s k i, Co na to inni rodzice?, tamże, s. 35.
100 N. D zi e w a n o w s k a, List, SiD 1957, nr 2, s. 5.
101 M. M a j c h e r c z y k, Czytelnicy piszą, SiD 1956, nr 12, s. 19.
102 K. P e l e c, Czytelnicy piszą, SiD 1957, nr 9, s. 15.
103 Por. Okólnik nr 8 z dn. 9 czerwca 1950 r. w sprawie wykonania postanowień ustawy o socjalistycznej dyscyplinie pracy, AAN, zespół: Ministerstwo Oświaty, sygn. 7303, k. 7-9.

104 Wypowiedź nauczycielki ze szkoły w Andrychowie ws. upowszechniania dzienniczka uczniowskiego: „Gdy rozpoczęłam pracę na nowej placówce, zastałam dzieci niezdyscyplinowane i lekceważące często regulamin uczniowski. Należało od razu opanować klasę i wdrożyć ją do systematycznej pracy. Z wielką pomocą przyszedł mi dzienniczek uczniowski prowadzony według wzoru podanego w czasopiśmie «Szkoła i Dom»”. E. G ołd o w a, Korzystamy z dzienniczka uczniowskiego, SiD 1952, nr 2, s. 28. 
skich. Rodzice po sprawdzeniu odrobionych zadań podpisywali dzienniczki"105. Rodzice zrzeszeni w tzw. trójkach klasowych również odnotowywali swoje opinie i spostrzeżenia, z których korzystali nauczyciele. Do tych celów np. w SP nr 34 w Łodzi KR „wprowadził specjalne zeszyty uwag. Jest to forma pracy nie wszędzie znana i stosowana, a przynosząca dobre wyniki"106. Nadawcy listów polecali też notatnik jako narzędzie, z jednej strony ułatwiające współpracę opieki klasowej z domem rodzinnym ucznia, a z drugiej pełniące funkcję ewidencyjną i kontrolującą. Notatnik - zdaniem jednej z członkiń opieki klasowej w Grudziądzu - powinien zwierać następujące elementy: nazwisko ucznia i miejsce zamieszkania; charakterystykę dziecka; warunki domowe ucznia; uwagi z odwiedzin w domu; uwagi nauczyciela ${ }^{107}$. W innej szkole w ramach opieki klasowej narzędziem kontrolującym okazał się zeszyt, co egzemplifikuje wypowiedź uczennicy SP:

Otóż nasza wychowawczyni zorganizowała na terenie naszej klasy kółko przedmiotowe języka polskiego. Zebrania odbywają się raz w tygodniu - i za każdym razem u innej koleżanki, pod opieką rodziców. Przewodnicząca każdej grupy prowadzi zeszyt, w którym zapisuje temat, obecność itd. A na koniec parę słów zapisują rodzice - czy pracowaliśmy sumiennie i jak zachowywaliśmy się ${ }^{108}$.

Wraz w wprowadzeniem zmian w regulaminie KR w 1954 r., również na łamach czasopisma korespondenci przypominali rodzicom o wykorzystywaniu w pracy wychowawczej w domu regulaminu uczniowskiego. Szczególnie dobitnie eksponował to zagadnienie korespondent z Warszawy: „Rodzice mogą i powinni (w swoim własnym interesie) znać regulamin szkolny” ${ }^{109}$. Warto też dodać, że wszelkie przejawy kontroli na terenie szkoły przeprowadzano nie tylko na zebraniach rodzicielskich, lecz także w formie propagandy w prasie ${ }^{110}$, aby poprzez wskaźnik podać konkretny dowód dokonującego się postępu (np. lepsze wyniki nauczania) ${ }^{111}$.

Współudział w urządzaniu uroczystości szkolnych i pozaszkolnych stanowił ważny element aktywności rodziców i nauczycieli. Nadawcy listów wypowiadali się na temat organizacji i przebiegu różnorodnych imprez i uroczystości, wśród których wymieniali np. uroczystość składania przyrzeczeń harcerskich ${ }^{112}$ lub zakończenie roku szkolnego połączone z wystąpieniem przewodniczącego KR oraz wręczaniem nagród i upominków uczniom ${ }^{113}$. W ramach pracy społecznej komitety rodzicielskie angażowały się w różnorodną działalność kulturalno-artystyczną. W SP w Łaziskach Średnich KR powołał Sekcję Teatralną, która wówczas była

105 K. A b r a m c z y k, Z pracy komitetów rodzicielskich, SiD 1953, nr 10, s. 31.

106 Z. Ma r cin i a k, Z pracy komitetów rodzicielskich, tamże.

107 m.a., O pracy rodzicielskiej opieki klasowej, SiD 1953, nr 12, s. 29.

108 Uczennica klasy VI a Szkoły Podstawowej w Poznaniu, Śladami przodowników, SiD 1952, nr 2, s. 28.

109 S. Giza, Moje uwagi o współpracy rodziców z nauczycielami, SiD 1954, nr 9, s. 27.

110 M. J. R a d z i s z e w s k a, Nauczyciele szkół powszechnych i podstawowych na Warmii i Mazurach (1945-1956), Kraków 2011, s. 121.

111 Walczymy o wyniki nauczania, SiD 1950, nr 2, s. 30-31.

112 E. Krzy w o bło c k a, Wielka uroczystość, SiD 1954, nr 5, s. 34.

113 J. Li w a r s k a, Niezapomniane chwile, SiD 1952, nr 8-9, s. 56. 
jedynym ośrodkiem kulturalnych w tej miejscowości i dlatego jej występy stały się „wielkim wydarzeniem artystycznym”14. Przy okazji analizowania kwestii imprez autorzy listów apelowali o zaprzestanie organizacji zabaw tanecznych połączonych z serwowaniem napojów alkoholowych, pomimo zmniejszenia dochodów i zwiększenia wkładu pracy ${ }^{115}$. Szczególnie popularną formą imprez był udział członków komitetów rodzicielskich w loteriach fantowych, co potwierdza wypowiedź przewodniczącej komisji naukowo-wychowawczej SP nr 8 w Warszawie:

Muszę Ci jeszcze, kochana Redakcjo, powiedzieć, że pomiędzy zbierającymi fanty wyłoniło się współzawodnictwo. Dzieci i rodzice byli z tej inicjatywy bardzo zadowoleni. Nasi rodzice zrozumieli, ze nie tylko swoja pracą zawodową lub społeczną przyczyniają się do budowy socjalizmu, ale osiągną ten cel, jeżeli dobrze, w duchu patriotyzmu ludowego, szybciej wychowają dzieci116.

Rodzice - członkowie komitetu rodzicielskiego wspierali działalność organizacji młodzieżowych, np. Szkolnych Kół Odbudowy Warszawy ${ }^{117}$, brali udział w obchodach Międzynarodowego Dnia Dziecka ${ }^{118}$, o czym skrzętnie donosili korespondenci miesięcznika „Szkoła i Dom”.

W ramach współpracy szkoły z rodziną ważne miejsce zajmowała dbałość komitetu rodzicielskiego o zaspokajanie potrzeb gospodarczych i sanitarnych szkół. Nadawcy listów informowali o podejmowaniu inicjatyw na rzecz poprawy warunków lokalowych budynków szkolnych oraz ich wyposażenia. W Szkole Podstawowej $\mathrm{nr} 7 \mathrm{w}$ Białymstoku członkowie Komitetu Rodzicielskiego podjęli się budowy sali gimnastycznej. Ten czyn sprawił, że - zdaniem przewodniczącego KR - „Rodzice są zadowoleni z dobrze spełnionego obowiązku względem szkoły i własnych dzieci. Rośnie autorytet aktywu szkolnego i komitetu rodzicielskiego, który może wiele zdziałać dla własnej szkoły”119. W innej szkole: „Komitet w zgodnej współpracy ze szkołą wybudował dom mieszkalny dla nauczycieli [...] świetlicę szkolną"120. W jednej ze szkół w powiecie wyrzyskim KR przeznaczył pierwsze fundusze na zakup pomocy naukowych, zasłon do okien w klasie, na zaopatrzenie biblioteki oraz wspierał organizowanie dwuletniej Szkoły Przysposobienia Rolniczego ${ }^{121}$.

W związku z rozpoznaniem potrzeb gospodarczych szkoły przez rodziców autorzy listów zwracali się do redakcji z prośbą o pomoc w załatwieniu różnych spraw, takich jak: wyjaśnienie ws. ubezpieczeń szkolnych ${ }^{122}$, zakup pomocy naukowych, np. mikroskopu („Będę Redakcji «Szkoły i Domu» bardzo wdzięczny.

114 A. Li s oń, Zaczęliśmy od... „Zemsty”, SiD 1954, nr 4, s. 32.

115 S. Wo y na ro w s k a, Zabawy rodzicielskie - ale bez wódki, SiD 1953, nr 8-9, s. 46-47.

116 J. Kacprzak, Dobre wychowanie dzieci..., s. 31.

117 A. Olkie w i c z, Wzorcowo pracuje Koło Odbudowy Warszawy w szkole nr 8 w Grudziądzu, SiD 1952, nr 1, s. 25-26.

118 C. Strzele c, Jak szkoły wiejskie obchodziły Międzynarodowy Dzień Dziecka, SiD 1953, nr 7, s. 31 .

119 J. B a rt n i c k i, Będzie sala gimnastyczna, SiD 1958, nr 1, s. 15.

120 J. J a k u b o w s k a, O komitecie rodzicielskim, tamże, nr 4, s. 14.

121 J. Ku b a c k i, Politechnizacja w miniaturze, tamże, nr 12, s. 16.

122 Redakcja, Ubezpieczenia szkolne, SiD 1951, nr 1, s. 30. 
Po feriach rozpocznie swą działalność «Kółko Młodych Miczurinowców» - tak bardzo przydałby się mikroskop”123. Odpowiedź redakcji: „“Cezas» na skutek interwencji naszej Redakcji zarezerwował dla Szkoły w Przeuszynie 1 mikroskop typu M-100"124) czy narzędzi stolarskich dla świetlicy w Szkole Podstawowej w Maszewie ${ }^{125}$. O interwencję przy remoncie szkoły prosił m.in. członek KR ze wsi Łuczyna w powiecie trzebnickim:

Szkoła nasza miała być pokryta całkowicie dachówką, a pokryto zaledwie 1/8 części dachu i na tym pracę zakończono. [...] Światły obywatel nie może patrzeć na tę sprawę obojętnie i mam nadzieję, że Redakcja wpłynie na odpowiednie władze ${ }^{126}$.

W powyższej sprawie „Redakcja interweniowała w Wydziale Oświaty PRN” i ostatecznie pomyślnie zakończono remont dachu ${ }^{127}$. Natomiast członkowie KR z miejscowości Klementowice w powiecie puławskim prosili o wskazówki dotyczące budowy budynku szkolnego. Redakcja w odpowiedzi na list udzieliła wyjaśnień i informacji potrzebnych przy podejmowaniu tej inwestycji ${ }^{128}$. Na łamach czasopisma, podobnie jak w innych periodykach, wzrosła liczba publikowanych listów wymagających interwencji i pośrednictwa redakcji. W tym celu w stałej rubryce "Czytelnicy piszą" albo w osobnych działach pojawiły się nowe kolumny, np. „Śladem Interwencji” 129 czy „Odpowiadamy...”"130. Zainteresowanie redakcji codziennymi sprawami czytelników zwiastowało nadejście Odwilży, dawało odczuć czytelnikowi, że jego potrzeby i oczekiwania też są brane pod uwagę ${ }^{131}$.

Osobne miejsce w zakresie współpracy szkoły z domem zajmuje podejmowanie zobowiązań przez komitety rodzicielskie. Zagadnienie to bardzo często było poruszane przez korespondentów i autorów listów prywatnych. Większość zobowiązań dotyczyła podjęcia się przez KR pomocy w zakresie osiągania dobrych wyników nauczania i wychowania, prac budowlanych, gospodarczych na rzecz poprawy funkcjonowania szkoły, ale były też zobowiązania, w ramach których KR postanowiły „prowadzić zdecydowaną walkę z przejawami chuligaństwa” lub deklarowały, „że więcej będą prenumerować i czytać czasopismo "Szkoła i Dom»"132. Treść niektórych propozycji wynikała z kalendarza imprez szkolnych, np. z okazji Święta Pracy KR zobowiązywały się do zakupu nagród książkowych dla przodowników nauki oraz dekoracji budynków szkolnych ${ }^{133}$. Przy okazji

${ }^{123}$ M. B ier n a t, Szkoła będzie miała mikroskop, tamże, nr 2, s. 32.

124 Redakcja, Szkoła będzie miała mikroskop, tamże.

125 Redakcja, Odpowiedź redakcji, tamże, nr 3, s. 30.

126 Śladem interwencji. Budynek szkolny pod dachem, SiD 1952, nr 3, s. 28.

127 Redakcja, Budynek szkolny pod dachem, tamże.

128 Redakcja, Budujemy szkołę, tamże, nr 7, s. 27.

129 Redakcja, Śladem naszych interwencji, SiD 1953, nr 1, s. 23.

130 Redakcja, Odpowiadamy... SiD 1954, nr 10, s. 38.

131 Por. M. Radzis ze ws ka, Kreowanie modelu nauczyciela szkoły socjalistycznej w prasie województwa olsztyńskiego w latach 1951-1956, [w:] Czasopiśmiennictwo drugiej połowy XX wieku jako źródło do historii edukacji, red. I. Michalska, G. Michalski, Łódź 2010, s. 81-82.

132 Redakcja, Czytelnicy piszą, SiD 1955, nr 1, s. 19.

133 Redakcja, Nasze zobowiązania, SiD 1954, nr 5, s. 34. 
uczczenia Święta Pracy treść zobowiązania KR przy Szkole Podstawowej w Wilamowie, w województwie olsztyńskim, została wyeksponowana pogrubionym drukiem z informacją: „Wzywamy wszystkie komitety do podejmowania zobowiązań dla uczczenia Święta Klasy Robotniczej"134. Kolejne zobowiązania KR podejmowały z okazji dziesięciolecia PRL, o czym informował list sekretarza KR Szkoły TPD nr 20 w Krakowie: „kierowniczka szkoły [...] zaproponowała, aby dla uczczenia dziesięciolecia PRL i dziesiątej rocznicy wyzwolenia Krakowa przez Armię Czerwoną, Komitet podjął zobowiązanie budowy piętra. Słowa jej trafiły do serc zebranych"135.

Na łamach czasopisma ukazywały się też treści zobowiązań, których autorami byli rodzice. W jednym z listów do redakcji napisali, że „postanowiono w czynie społecznym opodatkować się na rzecz budowy domu mieszkalnego dla nauczycieli w Konopnicy i rozbudowy szkoły w Stasinie"136.

Jedną z form wspierających systematyczne kontakty szkoły z domem rodzinnym są działania podejmowane sporadycznie bądź okresowo w zależności od potrzeb. Można do nich zaliczyć prowadzenie zajęć przez rodziców. Jedna z nauczycielek w liście do redakcji szczegółowo opisała przygotowywanie uczniów do egzaminów. Zwróciła też uwagę na rolę rodziców w tym zakresie:

Z dużą pomocą spieszyli nam także rodzice, którzy znając wymagania stawiane dzieciom przez szkołę w odpowiedni sposób kierowali pracą uczniów w domu. Wielu członków Komitetu Rodzicielskiego zorganizowało komplety douczania z przedmiotów egzaminacyjnych i innych. Douczanie to prowadzili rodzice przy pomocy nauczycieli ${ }^{137}$.

W zakresie propagowania wśród rodziców i społeczeństwa zasad postępowego wychowania dzieci w szkole i w domu autorzy listów wskazywali na obecność rodziców nie tylko na zebraniach, lecz także na apelach szkolnych. Jak relacjonuje nauczyciel - udział rodziców w apelach szkolnych „wpływa w dużym stopniu na podniesienie wyników pracy szkolnej”"138. Oprócz apeli doraźnymi formami pomocy rodzicom w rozwiązywaniu różnych kłopotów wychowawczych były m.in. odwiedziny rodziców i zakładów pracy, gdzie „przedstawiciele komitetów [...] wyjaśniają nieporozumienia, sygnalizują zaniedbania uczniów. W trosce o kulturę pedagogiczną rodziców zorganizowano Studium Rodzicielskie. [...] Oprócz wykładów wyświetlane są filmy o treści wychowawczej"139. Istotne znaczenie w tym zakresie spełniają też Uniwersytety Powszechne, a w nich zwłaszcza sekcje szerzenia wiedzy pedagogicznej dla rodziców ${ }^{140}$. Zachętę do sięgania po lektury z dziedziny wychowania odnajdujemy w poniższym fragmencie listu: „Trzeba, aby rodzice sięgali po nie, aby je czytali, aby książki stały się ich dorad-

\footnotetext{
134 Redakcja, Zobowiązanie, SiD 1955, nr 3, s. 19.

135 E. M il d n e r, Na dziesięciolecie, SiD 1954, nr 12, s. 26.

136 (wic.), Pożyteczna inicjatywa, SiD 1958, nr 5, s. 15.

137 A.S., Refleksje poegzaminacyjne, SiD, 1954, nr 9, s. 25-26.

138 K. Unie je w sk i, Rodzice na apelach szkolnych, SiD 1953, nr 5, s. 29-30.

139 K. C za rnom s k i, Studium Rodzicielskie, SiD 1958, nr 7-8, s. 25.

140 J. J ankowski, [bez tytułu], tamże, nr 10, s. 15.
} 
cami w pracy wychowawczej"141. Do bezpośrednich form współpracy rodziny ze szkołą zaliczyć należy „Regularne uczęszczanie na klasowe zebrania rodziców, pełnienie różnego rodzaju dyżurów w szkole, udział w pracach komitetu rodzicielskiego"142 oraz propagowanie wśród rodziców czytelnictwa książek i czasopism pedagogicznych ${ }^{143}$.

Natomiast z punktu widzenia nauczycieli w pogłębianiu współdziałania szkoły z rodzicami bezpośrednimi formami współpracy były: „odwiedziny domów rodzicielskich, rozmowy indywidualne nauczycieli z rodzicami, wspólne obserwacje zachowania się dziecka, korespondencja, dzienniczek uczniowski”"144. Nauczyciele w listach do redakcji zwracali też uwagę na sposoby komunikowania się z rodzicami:

W rozmowie z rodzicami nie ograniczajmy się jedynie do skarg i zażaleń. W każdym bowiem dziecku można znaleźć coś dobrego i od tego należałoby znaleźć rozmowę z rodzicami. Mówiąc zaś o ujemnych cechach ucznia, wskazujemy rodzicom środki zmierzające do poprawy jego zachowa$\mathrm{nia}^{145}$.

Wśród pośrednich form współpracy nauczyciela z rodzicami można wskazać w szkołach podstawowych „wieczorne repetycyjne lekcje otwarte, które mają częstokroć charakter wieczorów literackich”"146, zaś w przedszkolach „specjalne kąciki, w których znajdują się dobre książki o wychowaniu dziecka, plany pracy, jadłospisy i różne czasopisma"147.

Na odrębną refleksję zasługuje szczególnie popularna forma współpracy środowiska rodzinnego i szkolnego w okresie PRL, jaką jest kolportaż materiałów propagandowych i korespondencja. Zarówno czasopismo pedagogiczne „Szkoła i Dom", jak i prasa partyjna były uważane za samodzielny środek propagandowy lub „środek wspomagający agitację bezpośrednią"148. Dlatego też nie dziwi akcja rozpowszechniania pisma i obowiązkowej prenumeraty przez placówki oświatowe. Również w rubryce „Czytelnicy piszą” toczyła się polemika wokół wyników kolportażu. W listach korespondenci zapewniali o rozpowszechnianiu pisma ${ }^{149}$, jednocześnie podawali dokładne dane odnośnie do zaprenumerowanych egzemplarzy: „Wszystkie kierownictwa szkół podstawowych w powiecie płońskim w liczbie 96 zaprenumerowały po jednym egzemplarzu czasopisma «Szkoła i Dom» dla szkoły i po jednym egzemplarzu dla każdego Komitetu Rodzicielskiego"150. Na łamach czasopisma publikowano też wypowiedzi czytelników przyczyniające się do rozpowszechniania tego periodyku, do wskazania jego roli wychowawczej „na

141 Z. Vig el, [bez tytułu], tamże, nr 11, s. 15.

142 L. Tom a s zew s ka, [bez tytułu], tamże.

143 K. S z u be rt, W zamku świetlica, SiD 1957, nr 9, s. 16.

144 M. Majcherczy k, Czytelnicy piszą, SiD 1956, nr 12, s. 19.

145 W. Maj che r c z y k, O pracy z rodzicami, SiD 1957, nr 7-8, s. 31.

146 Redakcja, Czytelnicy piszą, SiD 1955, nr 3, s. 19.

147 J. U r b a ń c z y k, Dobrze pracujące komitety..., s. 46.

148 M. C z yżn ie w s k i, Propaganda polityczna..., s. 112.

149 F. S m y k, „Szkoła i Dom” pomaga w pracy, SiD 1951, nr 3, s. 28.

150 Wydział Oświaty Prezydium PRN w Płońsku, „Szkoła i Dom” pomaga w pracy, tamże. 
odcinku uaktywnienia Komitetów Rodzicielskich i ściślejszego powiązania ich ze szkołą [...]. Ażeby organ Wasz mógł zadanie to wykonać, musi być spopularyzowany, musi dotrzeć do każdego członka Komitetu Rodzicielskiego, do tysięcznych rzesz rodziców, stać się ich przewodnikiem i doradcą w wychowaniu dzieci”151. W numerze 11/1952 pojawił się list, w którym czytelniczka z entuzjazmem opisuje moment otrzymania czasopisma „Szkoła i Dom”:

W dniu 5 października 1952 r. na walnym zebraniu rodziców. Dzieci klasy Illa i Illb wręczyły rodzicom czasopismo „Szkoła i Dom” wraz z wiązankami kwiatów. [...] Rozczuleni tym serdecznym obrazkiem rodzice postanowili zbierać się w szkole raz na 2 tygodnie na tzw. "czwartki dyskusyjne” i omawiać zagadnienia poruszane w tym czasopiśmie. Prosimy wydrukować nasz list, aby tak samo postępowały inne nowo wybrane komitety ${ }^{152}$.

O akcji propagandowej zdobywania nowych prenumeratorów pisma informowali też nowi nadawcy listów do redakcji153. Czasopismo „Szkoła i Dom” nie ustrzegło się manipulowania opinią społeczną. Wyraźnie kreowało ideał stalinowskiej koncepcji wychowania dzieci154, co eksponuje wypowiedź jednego z późniejszych stałych korespondentów pisma: „Po przeczytaniu kilku numerów pisma doszedłem do przekonania, że przy jego pomocy i za jego pośrednictwem będę mógł lepiej służyć naszej wspólnej sprawie - wychowaniu nowego człowieka, wartościowego obywatela naszej Ludowej Ojczyzny"155. Czasopismo podporządkowane potrzebom propagandy zamieszczało obowiązkowy komentarz pod listami czytelników, podkreślający rolę i znaczenie komitetów rodzicielskich, jak np.:

Redakcja ze swej strony chciałaby dodać, że niemałą również zasługę nauczycielki J. Misygar jest dobrze działający Komitet Rodzicielski w Faliszówce. Młoda, zdolna i pełna zapału nauczycielska potrafi w najmniej dogodnych warunkach z Komitetem Rodzicielskim owocnie i zgodnie współpracować $^{156}$.

W innym dopisku pod korespondencją czytamy: „Redakcja miesięcznika «Szkoła i Dom» dziękuje za nadesłaną korespondencję i prosi o napisanie artykułu na temat: "Co zrobił Komitet Rodzicielski dla Szkoły w Ołpinach»"157. Odnośnie do zwiększenia udziału komitetów rodzicielskich w akcji zbierania złomu, szkła i papieru napisano: „Redakcja miesięcznika «Szkoła i Dom» sądzi, iż apel młodzieży zmobilizuje komitety rodzicielskie do tej ze wszech miar pożytecznej i wychowawczej akcji” ${ }^{158}$. W następnym numerze wypowiedź ta brzmi następująco: „Redakcja zwraca się z prośbą do przewodników Drużyn Harcerskich, aby w swych wypowiedziach dyskusyjnych uwzględnili pracę Komitetów Rodziciel-

${ }^{151}$ A. S ułk o w s k i, Dzielimy się doświadczeniami na łamach „Szkoły i Domu”, SiD 1952, nr 4, s. 30 .

152 Nowo wybrany KR SP nr 7 w Białymstoku, „Szkoła i Dom” w darze od dzieci, tamże, nr 11, s. 31.

153 E. Mild ne r, Jak nam pomaga „Szkoła i Dom”, SiD 1954, nr 5, s. 38.

154 K. J a ku biak, Problematyka wychowania..., s. 214.

155 J. Zielińs ki, Co na to inni..., s. 35.

156 Redakcja, Rodzice dziękują nauczycielce za ofiarną pracę, SiD 1951, nr 2, s. 30.

157 Redakcja, Do naszego korespondenta, tamże, nr 1, s. 30.

158 Redakcja, Młodzież zbiera złom, tamże, nr 2, s. 31-32. 
skich i Szkolnych Komitetów Opiekuńczych w organizacji harcerskiej"159. Oprócz obowiązkowych treści na łamach pisma pojawiały się też obowiązkowe przedruki listów z innych gazet (np. z „Gromady” ${ }^{160}$ ), a także publikowano listy adresowane do Ministerstwa Oświaty ${ }^{161}$.

Reasumując, z lektury i analizy publikowanych listów czytelników do redakcji miesięcznika „Szkoła i Dom” wynika, że na łamach pisma toczyła się dyskusja, wymiana zdań, refleksji, propozycji wokół zagadnienia współpracy środowiska szkolnego z domem rodzinnym. Choć współdziałanie przybierało różne formy, to jednak dominującym podmiotem w relacji szkoła - dom byli nauczyciele, a nie rodzice. Nie ulega wątpliwości, że pełniejszy obraz problematyki współdziałania rodziny ze szkołą w okresie PRL pozwoliłaby nakreślić analiza innych źródeł historycznych, w tym także listów w czasopiśmie „Rodzina i Szkoła”, będącym miesięcznikiem dla rodziców i wychowawców (1959-1989), stanowiącym kontynuację miesięcznika „Szkoła i Dom”.

159 Redakcja, O pracy w organizacjach młodzieżowych, tamże, nr 3, s. 30.

160 Redakcja, Rady narodowe troszczą się o szkołę, tamże, nr 2, s. 30-31.

161 T. Tchó r ze w s ki, Składam podziękowania Ludowej Władzy, SiD 1953, nr 6, s. 30. 